\title{
Regeneration of part of the historic fortified town of Monção, Portugal
}

\author{
J. P. Delgado ${ }^{1,2} \&$ A. Sá Machado ${ }^{1}$ \\ ${ }^{1}$ ACANTO Consultores, Braga, Portugal \\ ${ }^{2}$ Universidade Lusíada, Porto, Portugal
}

\begin{abstract}
The main purpose of the paper is to represent the revitalization plan for a major part of Monção. The aim of the plan was to transform the area into a new coherent system, having in mind that Monção owes much of its income to tourism-related activities. Monção, founded in the 13th century, is located in the Northwest border of Portugal, close to Spain, across the Minho. The "terroir" of the region made it possible to produce the Alvarinho, a wine exported overseas. The proximity with the border gave Monção opportunities for trade, but exposed it, in military terms. One of the main urban features is a 17th century fortification that enclosed the town until 1915, when the construction of a railway line dictated the demolition of its southern section. The railway made easier the exportation of wine, and brought new tourists. However, the closing of the line in 1990 left behind a site that is now deprived of urban purpose. The plan had to deal with the area of the abandoned line, the railway station, the broken fortress (a National Heritage), and the interweaving of these with the historical town core and the 1980s quarters. Also, the plan had to improve the area where, every year, the local population stages a fight between St. George and the Dragon, representing the dangers of dwelling here. The paper presents the results of the process, just before the plan is implemented on the site, demonstrating how the constraints of time, money and bureaucracy play a crucial role. It emphasizes the participation of the municipality, the national heritage authority and of the national institute of architects. The paper presents a series of conclusions that may help social scientists, policy makers and other practitioners in the process of planning similar situations.

Keywords: Monção, Portugal, 17th century fortification, revitalization plan, urban design.
\end{abstract}




\section{Introduction}

We would find some cheerful people in Monção, if we could visit the place in that distant year of 1915, and for the strangest of reasons: someone had just destroyed part of the defensive walls of their home town. Like the spearhead of a futuristic St. George, the shining new railway line had broken down the stone belly of the 17th century fortification. This meant that they could now export their unique Alvarinho wine by train, and that they could also welcome dozens of tourists to the local SPA resort. By the beginning of the 21st century, some ninety years later, a new generation of people from Monção had a more nuanced view of this situation. Maybe the destruction of the wall had not been such a good bargain, after all. New roads had now dictated the closing of the railway, and Monção was left with a spoiled, yet beautiful, fortification, plus the obsolete railway facilities. These were not always a pleasant sight for the tourists seeking the place, and tourists were needed for the growing of the economy. So, in 2005, the municipality decided to ask for entries to an international competition, aimed at providing a new urban design to the site of the broken walls and of the abandoned railway station (see fig. 1c).



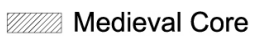

17th Century Fortification

Site Location

A: Monção; B: Valença; C: Paredes de Coura; D: Arcos de Valdevez; E: Melgaço

Figure 1: $\quad$ Site location: $\mathrm{a}$ - Iberian Peninsula; $\mathrm{b}$ - North-western frontier of Portugal; c - Monção.

The purpose of this paper is to present the winning entry to this competition, now fully developed into a construction project, as a case study for the renewal of a fortified site. The presentation is meant to be a way of sharing the experience of plans of this scope, such as they were commissioned, negotiated and drafted in Portugal, by the first decade of this century. The competition had 
the support of the national institute of architects (Ordem dos Arquitectos, or OA) and of the national heritage authority (at that time called Instituto Português do Património Arquitectónico, or IPPAR). The authors of this paper took part in the plan, both as project managers and senior architects. Although this is the first presentation in a meeting of this kind, the first stage of the plan was already published in a major architecture magazine in Portugal (Sá Machado et al. [1]).

The design team took in consideration the specific characteristics of Monção, which is a small Portuguese town (vila) of just about 2,500 inhabitants, and the seat of the municipality (concelho) of the same name. The municipality has an area of just over $210 \mathrm{~km} 2$ and a population of about 20,000 inhabitants. It is bounded in the west, south-west, south and east by the municipalities of Valença, Paredes de Coura, Arcos de Valdevez and Melgaço, respectively. In the north, the town faces the river Minho and, across it, the Galician municipality of Salvaterra (fig. 1a and b).

The plan was undertaken in three successive stages: the schematic design phase, the design development phase and the construction document phase. The documents produced were submitted to the different stakeholders, namely the municipality and IPPAR, with whom every critical detail was discussed before each subsequent stage.

After this introduction, the paper is organised in four parts and a conclusion. These parts are aimed at guiding the reader through the different steps of the methodology adopted by the design team, and contain provisional impressions about the design process and about future directions for research.

\section{Understanding the physical and historical framework}

Two major questions guided the team during the design process. First of all: how to approach a fragmentary urban reality, in the presence of traces of various heritages from different ages? And then: how to rank different historical layers, combining them into a coherent totality? In order to give adequate answers to these questions, the team made an effort to understand the different dimensions of time and space found in the region. As we will see, geographical features dictated historical aspects, and these dictated the development of the urban forms.

The name of the village may provide some keys to its understanding. It is possible that Monção owes its designation to its specific location. Marques [2] traces the origin of the word "Monção" from the Latin Mons Sanctus, meaning Sacred Hill. As a matter of fact, the town of Monção is located on a hill and is still encircled by a fortified wall, like many sacred places of the past. Among the scholars, such as Marques [3], a debate continues about whether the medieval town took the place of a former Celtic oppidum (known in Portugal and Spain as castro), or not. This seems possible, since various ruins of oppida remain in the region, like the Castro de São Caetano, $4 \mathrm{~km}$ to the north-east, and the Castros Monte Redondo and Cristelo, both at a distance of just about $2 \mathrm{~km}$.

A continuous history of war, all along the Early Middle Ages (involving, in a first phase, the Suevi and the Visigoths, and then, from the $7^{\text {th }}$ century on, 
various Christian kingdoms and the Moors) makes it impossible to trace a clear view of the settlement in this period. Reis [4] assures us that the town received its first charter (foral) in 1261, under the reign of King Afonso III. It was then fortified by order of King Dinis, in 1305 or 1308, as an important stronghold in a chain of fortresses constructed along the river Minho, in the $13^{\text {th }}$ and $14^{\text {th }}$ centuries, to defend the region against other Iberian kingdoms (see Andrade [5] and Marques [6]). Due to the impossibility of summarizing the evolution of the urban form of the village in the last six hundred years, fig. 2 shows a schematic view of how the urban fabric developed, from its medieval embryo until the mid$20^{\text {th }}$ century. The following paragraphs may be better understood with the help of these drawings.

In a synthetic way, it is possible to say that the location of Monção, close to a geographical and political frontier, is one of the three main historical factors that define the history of the place. The other two are, firstly, the fact that the town is the head of an important and very old wine region and, secondly, the presence of hot springs along the riverbank of the Minho. The interweaving of these three factors allowed us to establish a perspective of the succession of historical periods and of the urban development of Monção, as follows:

- Frontier - The borderline position was responsible for the need to build two defensive fortifications. As previously detected by Teixeira and Valla [7], as they studied the drawings of the $16^{\text {th }}$ century surveyor Duarte d' Armas [8], the first fortification, a medieval one, is recognizable in the lay-out of the central core of the town (fig. 2a). The stones of this old enceinte were used to build the second fortification, a bastioned fortress of the $17^{\text {th }}$ century, almost entirely preserved to this day (figure $2 b$ ). The periodical need for territorial protection determined the presence of military garrisons. Lepage [9] and Nunes [10] remind us that a defensive site is, first of all, a predetermined battleground. Pereira [11] claims that this specific and unstable situation may have marked the character of the inhabitants. The persistence of the "Coca Festival", every Corpus Christi day, often related to a fight between Good (St. George) and Evil (the Dragon, or Cocatrix), may be a manifestation of this anthropological substrate.

- Wine - The necessity of trading the Alvarinho wine was responsible for the building of the railway (figure 2c), allowing easy and fast exportations. Looking from the present, it is hard to fully grasp the promise of development and expansion that the train symbolised, back in 1915. The violence of the setting of the railway, exactly over the town wall, is probably nothing more than an "act of will" (proactive and dynamic) against an ancestral fortified confinement (passive and defensive).

- Water - The SPA resort took great advantage of the opening made possible by the railway, bringing a new dimension to Monção, one that was meant for tourists. The improvement of the SPA facilities changed the urban form of the town, as it generated new circuits between the central core and its outskirts, creating a new tension of growth towards east (figure 2c). The SPA resort represents, today, an inherent economic possibility for sustainable development, one that is specific of Monção, i.e. not entirely dependent of exterior impulses. 


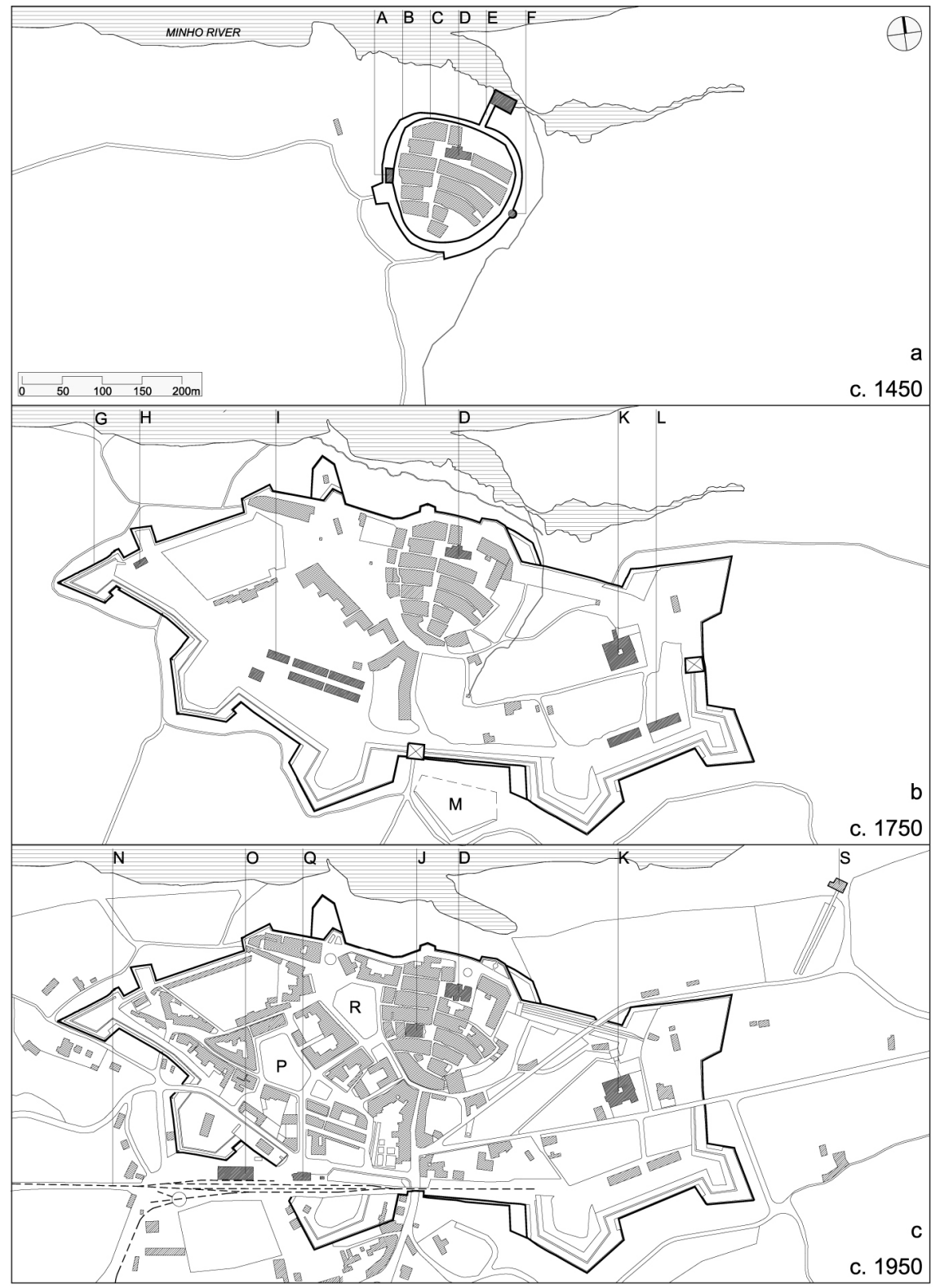

A: Donjon; B: Barbican; C: Enceinte; D: Parish Church; E: "Couraça"; F: Half-cylindrical Tower; G: Bastioned Fortification; H: Powder-magazine; I: Barracks; J: Town Council; K: Convent of the Capuchin Friars; L: Barracks; M: Ravelin; N: Railway; O: Railway storehouse; P: "Republica" Square; Q: Railway Station; R: Deuladeu Square; S: SPA Resort

Figure 2: $\quad$ Evolution of the urban fabric, from c. 1450 until c. 1950. 


\section{Identifying and interpreting needs and expectations}

The program for the competition was designed in a process that required the consensus of the multiple stakeholders involved, namely the municipality, OA and IPPAR. Each of them had a word to say in the setting of priorities, and they all had a representative member in the competition jury.

It was important for us to understand that this committee of stakeholders wanted the new plan to contribute for the promotion of the urban image of Monção, and also to that serve as a catalyst to a larger policy of urban and social development. In specific terms, we summarized 3 major urban intentions: (i) to promote the setting of much needed infrastructure in the area; (ii) to preserve and to add value to the fortification; (iii) to reinforce urban and social relations between historical core and recently developed areas.

The program document was so detailed as to state clearly 4 design principles every competitor should adhere to: (p1) reinforcement of a "street-like" spatial layout; (p2) respect for the image of the fortification, as a scenic framework of the local heritage; (p3) setting of a space with a strong character, in order to produce a positive impact over future buildings; (p4) use of architectural languages and scales suited to the existing urban fabric. As for new spaces and buildings, the program document was also very specific, and demanded for 3 types of construction: (c1) one mixed building (apartments and shops), 6 floors above ground; (c2) one mixed building (shops and offices), 2 floors above ground; (c3) one building (parking for 300 vehicles), 2 floors underground. The competitors were free to integrate the existing railway buildings, having always in mind the symbolic value of this heritage. The way to deal with the bastions was left entirely to the competitors. However, it was clearly stated that the Souto Bastion should be consolidated, in order to better accommodate the Coca Festival.

\section{Reading the site}

Before the geographical and historical framework of the place and the demands of the program, our next task was to conceptualize the character of our site. The three factors listed above (frontier, wine and water) had different impacts in the site of our plan. They all gave a contribution to its present outline (fig. 3b), with a central point in the former railway station, but with rather fuzzy limits. West of the station, the railway line was replaced by a thoroughfare resembling an avenue. This avenue links with the road that crosses the Minho in the new international bridge, but lacks any kind of urban design. East of the station, the railway line was replaced by a footpath that crosses the bridge of the South Gate and that directs to the Souto Bastion, were the "Coca Festival" occurs. The understanding of the urban facts present in the site allowed us to isolate 3 different moments, or overlapped historical "texts", forming what can described as the local "urban palimpsest": 


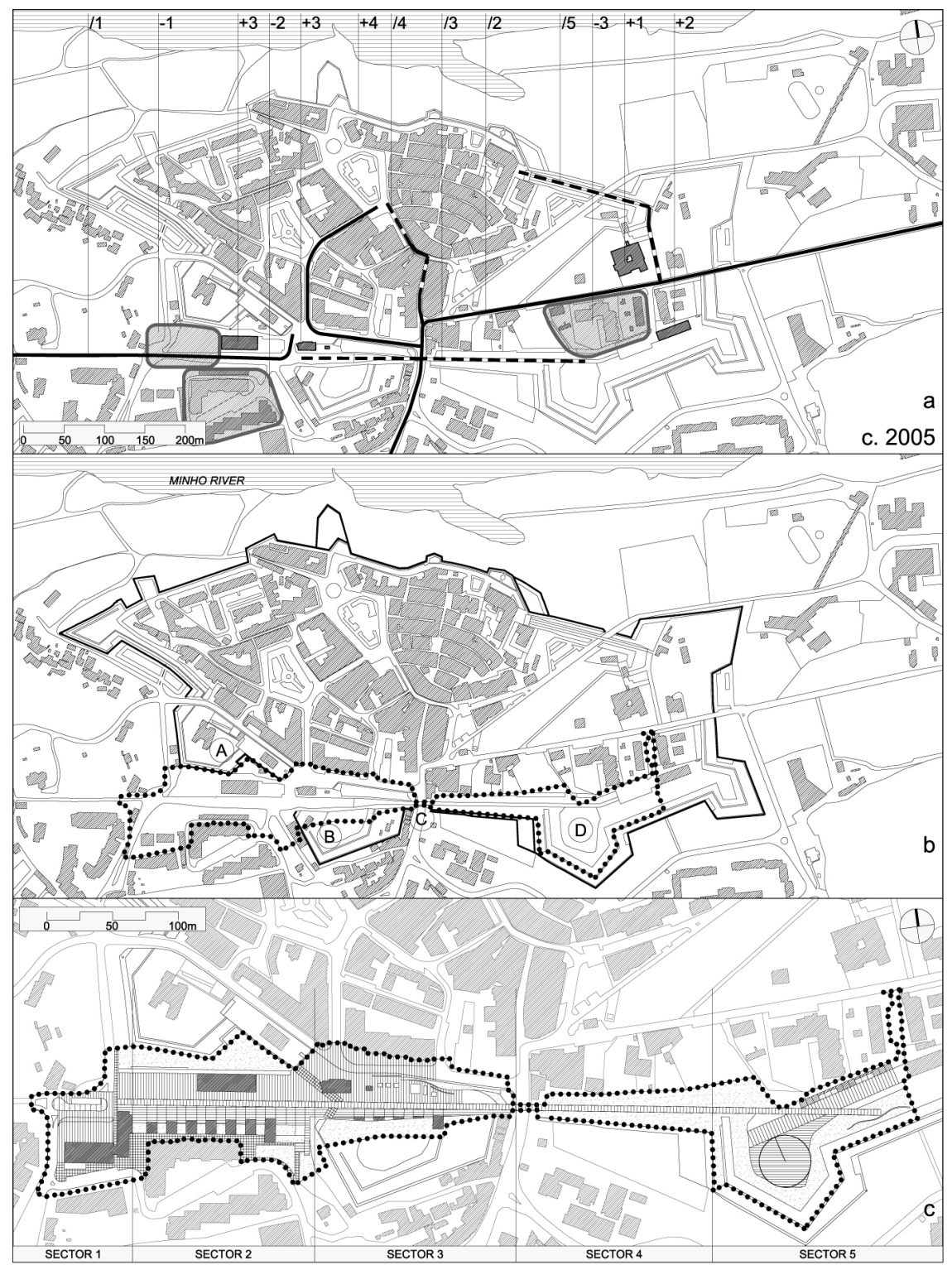

Site Location - - - Footpath system — Road network $\square$ Discordant areas

A: St John Bastion; B: St Anthony Bastion; C: South Gate; D: Souto Bastion +1: Convent of the Capuchin Friars; +2: Former Barracks; +3: Railway Facilities; +4: Fortress; -1: Area between St John and St Anthony Bastions; -2: Quarter of "Padrão"; -3: Building north of Souto Bastion; /1: "Railway" road network; /2: "South Gate" road network; /3: "South Gate" footpath; /4: Town center footpath; /5: Capuchin footpath

Figure 3: Designing a new urban system: a - Main buildings, spaces and networks (existing); b - Site location; c - Basic plan lay-out. 
- First moment: the construction of the bastioned fortress (mid $17^{\text {th }}$ century) The St John, St Anthony and Souto Bastions are the most obvious mark of this moment.

- Second moment: the construction of the railway (1915) - The station and the warehouse are the physical records of this presence. The demolition of the flank of the St Anthony Bastion is an evidence of the impact of this period over the former.

- Third moment: the closing of the railway (1990) - The embodiment of this moment is no longer a substantial, tangible trace but, quite on the contrary, a void. This void is an area of rarefaction and vagueness, not mitigated but reinforced by the inadequate presence of the new urban quarters, south of the area.

We called the resulting urban fabric an expectant fringe. We considered it a fringe, because it is both outside the traditional town core and outside the realestate speculation logic of the suburban quarters. And it is expectant because both its dimensions and its hinge position between the two above-mentioned areas (centre and periphery) grant it unique potential for urban, social and commercial development. On the other hand, the extensive area proposed by the competition, anticipates the possibility of redesigning new urban circuits, from the inside of the fortification to the outside, from north to south and from west to east.

As a methodological starting point, and since the site is punctuated by different architectonic and urban elements, it was important to establish a hierarchy of heritage value for existing buildings and spaces. To simplify this exposition, fig. 3a ranks these elements, according to the impact they produce. The sign is $(+)$ for positive and (-) for negative, but keeping in mind that most positive elements have also negative influences (e.g. state of conservation or inadequate use). Moreover, we considered that the motivation for the setting of the competition had been the resolution of the conflicts posed by the circulation of cars. Therefore, the exercise of establishing a hierarchy of buildings and spaces would not be complete without an appreciation of the movements connecting them. This analysis is listed as (/), and shows that all the circuits lead to the square in front of the former railway station $(+3)$. This area is obviously under the pressure of some heavy traffic. The situation is now critical, not only because this traffic is difficult to control, but also because this traffic produces a great impact over a delicate urban fabric.

\section{Designing a new urban system}

The plan was then drafted, having in mind all that have been studied before. Fig. 4 shows a general view of the final result, and some rendered $3 \mathrm{~d}$ perspectives that help understand the general lay-out. This plan was developed having in mind 5 design criteria: (c1) to use a composition strategy allowing the creation of contiguous but autonomous sectors; (c2) to fully respect the program; (c3) to preserve and to enhance the fortress, as founding primary element of the urban space; (c4) to preserve and to enhance the railway buildings, both as records of 
an important historical layer and as important elements in the definition of existing and proposed urban morphologies; (c5) to rearrange the traffic lay-out, refusing to transform the area in a mere "plateau" for traffic distribution. Criterion (c1) shows how important it was for the design team to find a flexible solution. This way, the plan may be implemented by phases, according to different combinations, under different economical situations. The importance of this criterion is evident in the selection of the main element of the design structure, the railway line. In our plan, this line is re-materialized as a new footpath that organizes the urban form into 5 sequential sectors.

This main element fulfils 5 functions of urban design: (f1) to set a central axis of reference for the main footpath and for all secondary ones; (f2) to relate existing and proposed buildings and spaces; (f3) to organize and to control road traffic circuits, above ground; (f4) to organize and to control parking circuits, underground; (f5) to help the "reading" and the enjoyment of the new townscape, from "anthropological and ancestral" (as found in the eastern part of the plan, with a new ring for the Coca Festival) to "cosmopolitan and contemporary" (as found in the western part, with a new hotel). By choosing this element, we wanted to give credit to an existing line of force and to acknowledge the importance of the railway for the urban form of Monção. This line had been very important in the laying-out of the railway facilities and, later on, in the setting of the suburban quarters. Moreover, as we have explained before, the railway line had some affinity with the design of the fortress, since it had taken the precise alignment of one of its curtains and of the South Gate.

In Portugal, railways are called "iron ways". So our "foot-way" will have iron parts and will have its colour. It will be modulated in segments of $2.50 \mathrm{~m}$ (about $8 \mathrm{ft}$ ), with sub-modules of $0.31 \mathrm{~m}$ (about $1 \mathrm{ft}$ ). These basic dimensions allowed us to design all elements of minimal scale, namely urban furniture, lighting fixtures and pavements. The grouping of $2.50 \mathrm{~m}$ segments permits the design of major elements, such as buildings and exterior spaces, until a limit of $150 \mathrm{~m}$ (about $164 \mathrm{yd})$. This is the main dimension of four of the five proposed sectors. Following former research (Delgado [12]), we wanted to relate this modulation of space and matter to a modulation of time and movement. So, we figured that the setting of sectors measuring $150 \mathrm{~m}$ in length will correspond to walks of about 2 minutes, for a common pedestrian, pacing a "promenade" of about 9 minutes in full. The former railway station will be considered "ground zero" of the plan, as it rests exactly over the foundations of the demolished curtain. It will serve as a "hinge building" between the existing fabric and the proposed plan, and between these and the car parking underground.

Each one of the 5 proposed urban sectors was carefully detailed, according to 8 references: (r1) name of the urban sector; (r2) length and distance to the "railway station"; (r3) expected time of walk; (r4) existing neighbouring buildings; (r5) main elements in the existing townscape; (r6) proposed urban and architectural program; (r7) proposed urban improvement; (r8) type of proposed building works. This conceptual grid kept us in full control of the design process, along all different stages, from the early ideas to the final construction documents. 


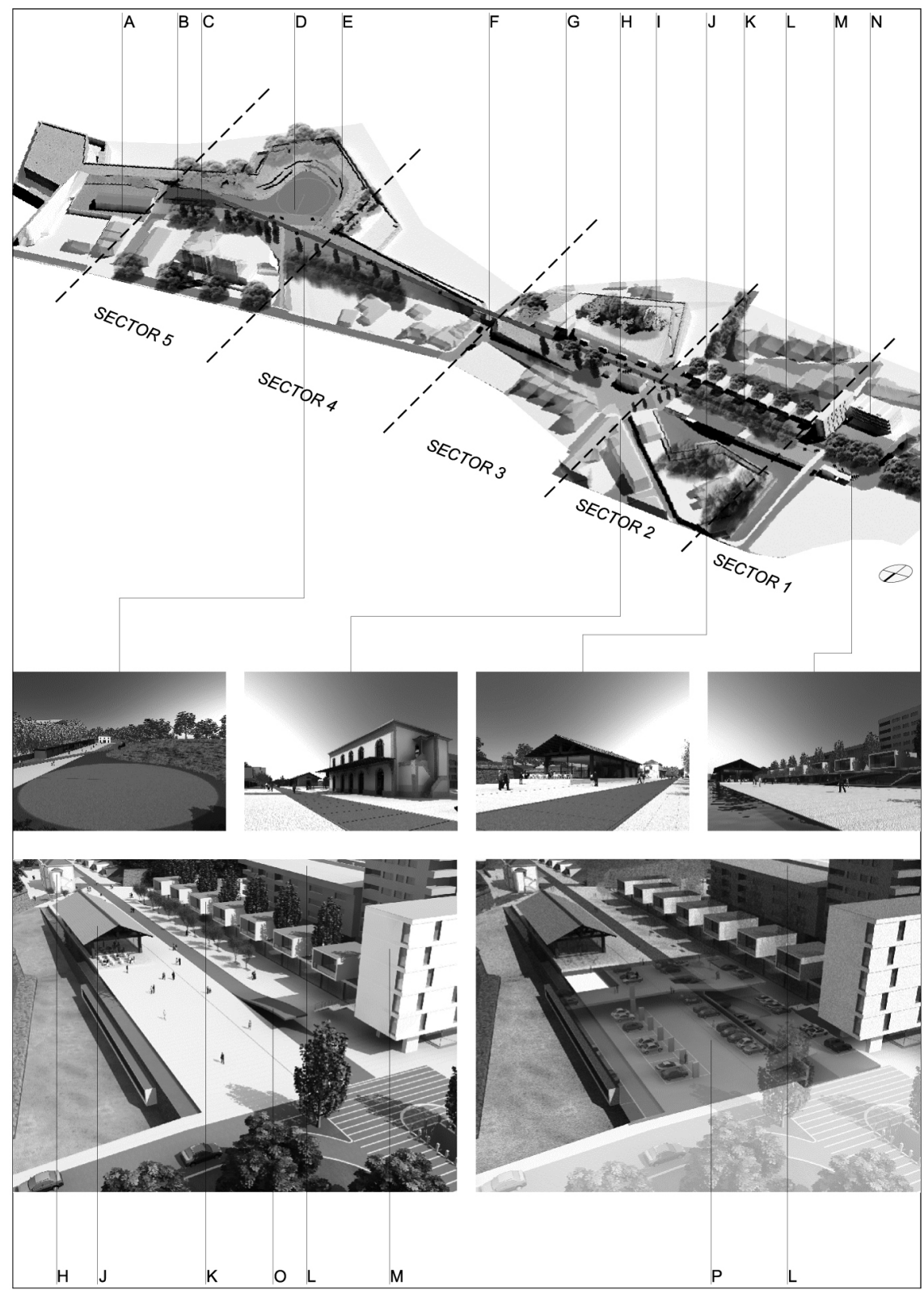

A: Former barracks; B: Coca sculpture; C: Bar; D: Coca ring; E: Souto Bastion; F: South Gate; G: Shops; H: "Railway station" ("Ground Zero"); I: St Anthony Bastion; J: "Railway storehouse" (restaurant); K: Shop and offices; L: Quarter of "Padrão" (existing); M: Hotel; N: Apartments building; O: Car parking entry; P: Car parking

Figure 4: Aerial view of the new urban system. 


\section{Drawing conclusions}

The built result is the best conclusion of most architectural tasks and, as we have said before, the plan has not left the drawing board, yet. Nevertheless, it is already possible to advance some provisional impressions that may be useful for other practitioners, social scientists and policy makers in the process of planning similar situations.

- Conclusions related with the design process:

1) In this case, one central, spinal theme guided the entire design process. We managed not to abandon it as our major design pattern. It was especially important, as we were very open-minded towards the different stakeholders, and welcomed every suggestion they made. The central element proved to be a true "line of force" that kept the final result coherent, neat and uncluttered.

2) The creation of different sectors proved to be correct. We have used it in every stage of the process, and it was very useful in the production of every document, making all tasks manageable and affordable. As for the construction process, this approach is now more useful than ever, since the economical crisis makes it impossible to build everything at once.

3) To this day, we still think that we gave a valid answer to the challenge presented by the site and by the program. However, a new hypothesis came to our minds, as we went through the design process. The underground parking, for instance, could have been designed in a different way (e.g. to double as exhibition area), in order to become more integrated with the daily life of the town.

- Conclusions related to the stakeholders:

1) The plan, although not built yet, has proved to be a way for the municipality to keep the area free of undesired real-state pressure.

2) On the contrary, the existence of the plan has attracted private investment to the surrounding area, specially the one related with tourist and leisure activities.

3) The main challenge is now to attract more "virtuous" private and public investment, in order to implement the entire plan, even if by stages.

This challenge is not specific to this town. It is a challenge that is common to all places that have rich assets, but not so rich incomes. But it is one that Monção has to face, in order to make its people happier, once again.

\section{Acknowledgements}

The authors wish to thank the members of the design team, for their support and assistance with this project, and especially Mr Virgílio Torres, for helping to produce this paper.

\section{References}

[1] Sá Machado, A.; Delgado, J.P., Nunes, A. A. and Gonçalves, S., Estudo prévio do arranjo urbanístico da zona da antiga estação da $\mathrm{CP}$ - Monção. Arquitectura Ibérica, 24, pp. 18-25, 2008. 
[2] Marques, J.A.M., Necrópole de Cortes (Mazedo - Monção). Revista da Faculdade de Letras: História, N.1, pp. 211-223, 1984.

[3] Marques, J. A. M., Assentamentos castrejos do Concelho de Monção, Revista de Ciências Históricas da Universidade Portucalense, Vol. II, pp. 77-120, 1987.

[4] Reis, A. M., O Foral de Monção, Sep. Mínia, N. ${ }^{\circ 10,}$ III série, pp. 103-146, 2002.

[5] Andrade, A. A., A estratégia dionisina na fronteira noroeste, Revista da Faculdade de Letras: História, Vol.15, pp. 163-176, 1998.

[6] Marques, J., Os municípios na estratégia defensiva dionisina, Revista da Faculdade de Letras. História, Vol. 15, pp. 523-544, 1998.

[7] Teixeira, M. C. and Valla, M., O urbanismo português: Séculos XIIIXVIII: Portugal-Brasil, Livros Horizonte: Lisbon, 1999.

[8] Duarte d'Armas, Livro das Fortalezas, Edições INAPA: Lisbon, 1997

[9] Lepage, J. D., Castles and fortified cities of medieval Europe: An illustrated history, 2nd ed., McFarland \& Company: USA, 2002.

[10] Nunes, A. L. P.; Dicionário de Arquitectura Militar, Caleidoscópio: Casal de Cambra, 2005.

[11] Pereira, P., Espírito da Terra, Enigmas, lugares mágicos de Portugal, Vol. VII, p. 77, 2005.

[12] Delgado, J. P., O lugar da arquitectura - notas para uma estética da edificação. GEHA - Revista de História, Estética e Fenomenologia da Arquitectura e do Urbanismo, N. ${ }^{\circ}$ 2/3, pp. 255-264, 1999. 